\title{
AIRSPORA OF GROUNDNUT FIELD AT NEWASA (M.S.)
}

\author{
1Arsule C.S.* and ${ }^{2 P a n d e ~ B . N .}$ \\ ${ }^{1}$ Department of Botany, New Arts, Commerce and Science College, Ahmednagar \\ ${ }^{2}$ Department of Architecture, MGM's Jawaharlal Nehru Engineering college, Aurangabad \\ ${ }^{*}$ Corresponding Author: csarsule@gmail.com
}

\begin{abstract}
:
Aero mycological Survey over a peanut (Groundnut) field was undertaken by operating an At Tilak Air sampler for two consecutive crop seasons. i.e. Kharif and Rabi. In all, 33 fungal spore types were identified and their incidence was correlated with the prevailing weather conditions. Cladosporium, Alternaria, Curvularia, Aspergillus, Cercospora were the dominant spore types. Spores of Cercospora sp. were recorded with maximum percentage in Kharif $(2.23 \%)$ than in Rabi $(1.75 \%)$ The percentage of disease incidence and intensity of disease index was also higher in the season Kharif than the Rabi season. Rust disease was recorded only in the Kharif season. The concentration of rust spores (Urodiniospores) in air was comparatively more in Kharif (4.837\%) than Rabi (3.63\%).
\end{abstract}

Key words: - Kharif, Cercospora, Rabi.

\section{INTRODUCTION:}

Pea nut (Arachis hypogea L.) is an important oil seed crop and is widely cultivated in tropical and subtropical developing countries, providing valuable source of proteins (20.45\%), fats (23.8\%), energy (2800 cal.) and minerals (Enwere, 1998). Peanut is a leguminous crop is important both as a subsistance crop and a animal feed. Peanut is affected by a various fungal, viral and pest diseases. The forecasting of airborne fungal diseases can be attempted if the information on the air-spora of this crop is available. Such work was carried out in some parts of India (Shanti, 1960; Sulaiman and Agashe 1964; Sreeramulu, 1970; Mallaiah and Rao 1980; Mallaiah, 1989, Kalkar and Palil. 1994.) and the present study represents Newasa dist. Ahmednagar (M.S.). In view of the above, airospora studies were conducted over Peanut fields in Kharif 2015 and Rabi 2016 and the results are presented in this paper.

\section{MATERIALS AND METHODS:}

The Study site was the Peanut farm close in proximity of Newasa town. The field lies in the district Ahmednagar, Western Maharashtra, 913.11 Variety of Peanut crop was available in both Khanif (July to October 2015) and Rabi (February to May 2016.) (Table -1).

Air sampling was done for two consecutive Seasons, Kharif, form 1st July to 30 October 2015 and Rabi, from 2nd February to 31st May 2016. Air spora was estimated by using the Tilak Air Sampler (Tilak and Kulkarni 1970) was kept at a constant height of 0.75 meter above ground level. The Process of air sampling started one week before the sowing the seeds of peanut crop and extended 7 days more after the harvesting of the crop in Kharif and Rabi seasons crops respectively.

Meteorological data was maintained throughout the field experimental period. The diseased material from the field, once in a week, was collected for assessing and confirming the disease incidence. Scanning of aerobiological slides and further calculations were done by using the method described by Tilak and Srinivasulu (1967). Identification of trapped fungal spore types was done on the basis of morphology 
and authentic slides prepared from the known fungal infected materials (Ellis,1976, Barnett, and Hunter, 1998). The circadian periodicity of the pre dominant genera was studied (each for two hours) for 24 hours once in a month.

\section{RESULTS AND DISCUSSION:}

During the period of investigation, the study enabled to identify 33 types of fungal spores at the generic level. Which numerically made up $67.62 \%$ of the total airspora of the 33 spore types. 1, belongs to Zygomycotina, 7. To Ascomycotina, 5 to Basidiomycotina, and 20 to Deuteomycotina. The spore types of Deuteromycotina dominated (56.14\%) followed by Basidiomycotina (6.56\%), Ascomycotina $(2.84 \%)$ (Table 3). Whereas the Zygomycotina was represented by only one member, Rhizopus. It contributed $2.84 \%$ to the total Airspora.

The group Ascomycotina is contributed (7.24\%) little bit higher in Kharif than in the Rabi (4.10\%). Occurrence of different types of ascospores in March was only due to occasional rain. No ascospore types were recorded in the months of April and May. Thus, the Seasonal Maxima was observed in rainy season. The effect of the rain on the catches can be classified into two types, immediately or delayed. The ascospores of Didymosphaeria were recorded immediately after the rain while the ascospores of Leptosphaeria, Pleospora and Sordaria sp. sometime after the raining. Spores of Pleospora and Sordaria were observed even 1-2 days after the rain. Gregory and Hirst (1957) observed that ascospores occur in abundance after the rains. Same observation was recorded by Sreeramulu (1967). High humid conditions and low temperature was also found to be favorable for the occurrence of these ascospores in air.
Rust spores (Urediniospores) of Basidiomycotina contributed $8.06 \%$ in Kharif season while $4.44 \%$ in Rabi to the total airspora. Occurrence of rust spores of basidiomycetes in large number in Kharif than Rabi may be due to rainy conditions in the Kharif season. Their prevalence can be very well correlated with the rainfall rather than vegetation of the area. These results are in accordance with the findings of Sreeramulu and Ramalingam (1966), Kalkar and Patil (1944). Sreeramulu (1967) suggested that the Basidiospores appeared in highest numbers after stopping of the rains. Occurrence of the members of Deuteromycotina irrespective of weather conditions hence these spores were noticed throughout the period of investigation.

Among the types of fungal spores, it is evident that Cladosporium (20.87\%) dominated the airospora followed by Alternaria (15.69\%), Nigrospora (4.55\%) Curvularia (4.19\%), Cercospora $(2.23 \%)$ etc.

The spore type like Cerospora personata and Cercospora arachidicola (Causing tikka disease) were only $20.05 \%$ of the total airspora. Their total concentration in Kharif was comparatively more than in Rabi season. Tikka disease was evident in both the seasons. Both the occurrence of Cercospora spore types in air as well as infection on leaf's (Tikka disease) was noted when there was no rainfall. Rains, might be responsible for washing off the leaf surface. Hence no record of these spores in rainy days. However, high humidity and optimum temperature showed as positive effect.

During Kharif season the first occurrence of Cercospora spores was recorded on 21 st July, 2015 While tikka disease appeared from 9th. August 2015. During the Rabi season spores of Cercospora were recorded from 27th February 
2016, but tikka disease was evident from 19th March 2016 onwards.

The concentration of Cercospora sp. in air in first kharif season was more or less constant in July and August, but later on it increased in September and again decreased in October 2015 while in Rabi Season, atmospheric condition of these pathogenic spores got increased from February to April and again got decreased in May 2016.

Rust disease caused by Puccina arachidis appeared first on 10th August, 2015. The disease occurred along with Tikka disease. It was absent in Rabi, though the considerable number of spores were trapped.

These investigations would be helpful in evolving an efficient disease forecasting system and preventing the ground nut crop from various air borne diseases like rust and tikka disease. Thus, it will help Phyto pathologists and agriculturists of this region in solving the problems on disease epidemics of ground nut.

\section{REFERENCES:}

Arsule, C.S. and Pande, B.N. (2012)." Aeromycology of Cercospora on Groundnut at Newasa (MS).” Int. Nal. Jr of Pl. Protection 5 (1): 8-11.

Enwere, N.J. (1976). Food of plant origin. Agroorbis Publication Limited Nsukka, NIGERIA: PP.: 301.

Kalkar, S.A. and Patil, G.R (1994). Fungal Air spora of a Ground nut Field at Nagpur: in 5th int. Nat. Conf. Bangalore- 1994
Aerobiology Edt. S.N. Agashe, Oxford \& IBH Publishing Co. PVT. Ltd., New Delhi PP: 249-254.

Mallaiah, K.V. and Rao, A.S. (1980). Aerobiology of two species of Cerospora Pathogenic to groundnut. Ind. Nat. sci. Acad. 46: 215222.

Mallaiah, K.V. (1989). Aerobiology of Cercospora species Pathogeic to crop Plants. Recent Res. Eco. Env. and Pol. 3: 67-78.

Shanta, p. (1960). Studies on Cercospora leaf spot of Ground nut (Arachis hypogea L.) I Effect of environment factors on disease incidence and on survival of the pathogen. J. Madras Unt. 30:167-177.

Sreeramulu, T. (1970). Conidial disposed of two species of Cercospora causing Tikka Leaf spots on Ground nut (Arachis hypogea L.) J. Agric. Sci. 40 :173-178

Sreeramulu and Ramalingam (1966). A two-year study of the airospora of Paddy field near Visakhapatnam. Ind. J. Agric.Sci. 36: 112-132.

Sulaiman, M. and Agashe, M.C. (1964). Influence of Climate on the incidence of Tikka disease of ground nut. Ind. Oli (seeds) 2 :176-179.

Tilak, S.T. and K. Kulkarni, R.L. (1970). A new air. Sampler Experientia 26(4): 443-444.

Tilak, S.T., Srinivasulu, B.V. (1967). Air spora of Aurangabad. Ind. J. Microbilo., 7:167170 . 
Table 1: Reveals season wise duration of the crop and air sampling

\begin{tabular}{|l|l|l|l|l|}
\hline Season & $\begin{array}{c}\text { Sowing date/ } \\
\text { Sampling started }\end{array}$ & Harvesting date & Sampling Stopped & Duration of Crop \\
\hline Kharif & $1^{\text {st } J u l y ~ 2015 ~}$ & $16^{\text {th }}$ Oct.2015 & $22^{\text {nd }}$ Oct.2015 & 109 days \\
\hline Rabi. & $2^{\text {nd }}$ Feb. 2016 & $2^{\text {rd }}$ May, 2016 & $31^{\text {st }}$ May, 2016 & 112 days \\
\hline
\end{tabular}

Table-2: Reveals Percentage Contribution of each group of the Season's airospora and to the total airospora.

\begin{tabular}{|c|l|c|c|c|}
\hline Sr. No. & Name of groups & Kharif $\%$ & Rabi \% & Total \% \\
\hline 1. & Fungal spores & 72.70 & 60.33 & 67.72 \\
\hline 2. & Pollen grains & 13.52 & 17.25 & 15.03 \\
\hline 3. & Other Types & 13.77 & 22.29 & 17.23 \\
\hline
\end{tabular}

Table-3: Reveals Class wise Percentage Contribution of Fungal Spores to the to the season wise airospora (Kharif \& Rabi) and to the total airospora (Kharif and Rabi).

\begin{tabular}{|c|l|c|c|c|}
\hline Sr. No. & Name of Class & Kharif \% & Rabi \% & $\begin{array}{c}\text { Total airspora \% } \\
\text { (Kharif + Rabi) }\end{array}$ \\
\hline 1. & Zygomycotina & 4.0 & 1.13 & 2.84 \\
\hline 2. & Ascomycotina & 7.20 & 4.10 & 5.95 \\
\hline 3. & Basidiomycotina & 8.0 & 4.42 & 6.59 \\
\hline 4. & Deuteromycotina & 55.38 & 50.70 & 52.24 \\
\hline
\end{tabular}

